\title{
Review
}

\section{Bronchiolitis Obliterans}

Talmadge E. King, Jr.

National Jewish Center for Immunology and Respiratory Medicine, Denver, Colorado, USA

\begin{abstract}
Bronchiolitis obliterans in the adult patient is a relatively uncommon and vexing clinical entity. This confusion results because this pathologic finding occurs in a variety of diverse clinical settings. Bronchiolitis obliterans is a fibrotic process that primarily affects the small conducting airways. The lesion results from damage to the bronchiolar epithelium and the repair process leads to excessive proliferation of granulation tissue. The alveoli adjacent to the small airway are almost always involved; however, a considerable portion of the interstitium is usually spared. The findings in these patients may physiologically and radiographically mimic chronic obstructive pulmonary disease (COPD). On the other hand, some of the processes associated with bronchiolitis obliterans result in restrictive or mixed restrictive and obstructive ventilatory defects; consequently, they may be confused with other diffuse infiltrative lung disorders. This review will focus principally on bronchiolitis obliterans in adults, which, until recently, was considered rare. There has been heightened interest in this process in adults because of its association with the connective tissue diseases, its development following toxic fume exposure, its occurrence as a result of chronic graft versus host reactions, and the increasing recognition of patients with idiopathic forms of the disease that have an insidious onset often confused with more common problems such as COPD or idiopathic pulmonary fibrosis.
\end{abstract}

Key words: Bronchiolitis obliterans-Inhalation, toxic fumes-Bronchiolitis-Pneumonia, organizing-Connective tissue disease.

\footnotetext{
* Address offprint requests to Talmadge E. King, Jr., M.D., National Jewish Center for Immunology and Respiratory Medicine, 1400 Jackson Street, Denver, CO 80206, USA
} 


\section{Introduction}

Bronchiolitis in the adult patient is a relatively uncommon and vexing clinical entity [67]. This confusion results because this pathologic finding occurs in a variety of diverse clinical settings. Furthermore, inflammatory processes involving the "small airways" may initially go "unnoticed" in the adult because the resistance of the peripheral airways falls considerably after approximately age 5 and thus leaves the small airways of the adult relatively silent, physiologically and symptomatically [57]. As the disease progresses and becomes clinically evident, many of the findings in these patients may physiologically and radiographically mimic chronic obstructive pulmonary disease. On the other hand, some of the processes associated with bronchiolitis result in restrictive or mixed restrictive/obstructive ventilatory defects and may be confused with other diffuse infiltrative lung disorders. In addition, different terms have been applied to these diseases, based mainly on the pathologic descriptions: bronchiolitis obliterans, bronchiolitis, bronchiolitis obliterans with organizing pneumonia, bronchiolitis fibrosa obliterans, bronchiolitis and diffuse interstitial pneumonia, follicular bronchitis/bronchiolitis, and small airway disease.

This review will focus principally on bronchiolitis obliterans in adults, which, until recently, was considered rare (Table 1). There has been heightened interest in this process in adults because of its association with the connective tissue diseases, its development following toxic fume exposure, its occurrence as a result of chronic graft versus host reactions, and the increasing recognition of patients with idiopathic forms of the disease.

\section{Bronchiolitis obliterans of known etiology}

Bronchiolitis obliterans is a fibrotic lung disease that primarily affects the small conducting airways, often sparing a considerable portion of the interstitium. The lesion results from damage to the bronchiolar epithelium and the repair process leads to excessive proliferation of granulation tissue. The alveoli adjacent to the small airways are almost always involved [33]. Until recently there have been only case reports describing this lesion in various clinical settings. Consequently, any uncertainties regarding the epidemiology, pathophysiology, long-term sequelae, and therapy of bronchiolitis obliterans exist.

\section{Toxic Fume Inhalation}

Toxic fume exposure, especially to "nitrous fume," may cause acute respiratory failure as a result of pulmonary edema and the development of the adult respiratory distress syndrome (ARDS), leading in some cases to death (either acutely or after a $4-6 \mathrm{~h}$ latent period). It is now recognized that toxic fume exposures are a significant industrial and environmental hazard occurring in a number of settings, for example, among agricultural workers (silo filler's dis- 
Table 1. Clinical classification of bronchiolitis obliterans

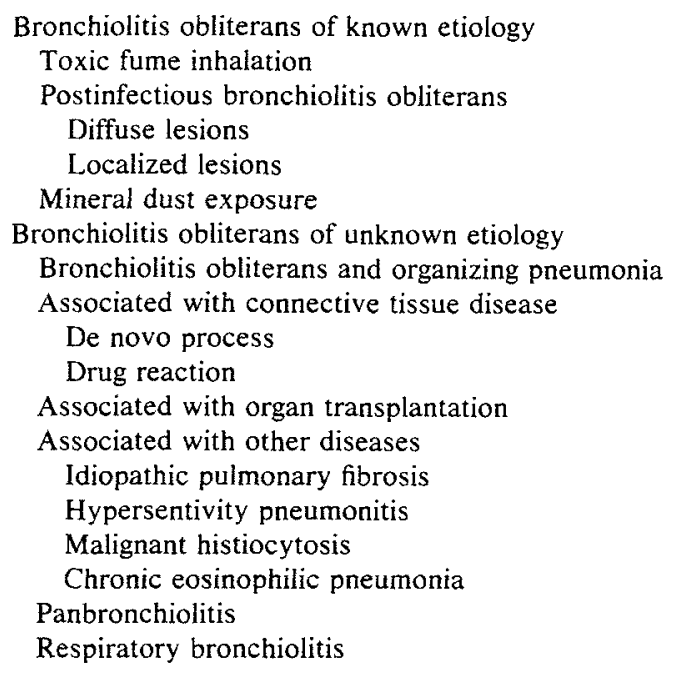

ease), chemical workers, munition and missile industries, gold and coal mining, and arc welding in confined spaces $[60,98]$ (Table 2).

Three clinical patterns may follow exposure to these toxic gases in those who survive the initial insult $[59,85,97,99,126]$. First after mild exposure individuals may develop any 1 of several findings: cough, dyspnea, fatigue, cyanosis, vomiting, hemoptysis, arterial hypoxemia, vertigo, somnolence, headache, emotional difficulties, and loss of consciousness. These usually resolve in hours but may persist for several weeks before complete recovery. Second, at higher concentrations of exposure, pulmonary edema frequently occurs. These patients may have mild or no symptoms at the time of exposure, only to develop a clinical picture of severe ARDS several hours later (3-30 h). Recovery is usual but death may occur at this stage. Finally, after recovery or in patients who had no initial illness following exposure, there may be a recurrence or onset of illness a few weeks later (2-6 weeks). This phase is characterized by the onset of a nonproductive cough, dyspnea, and an irreversible obstructive ventilatory defect (i.e. bronchiolitis obliterans) $[25,35,85]$.

The roentgenographic pattern of bronchiolitis obliterans is variable. Most commonly a miliary or discretely nodular pattern occurs and is considered characteristic of this type of bronchiolitis obliterans [25, 59, 85, 91] (Fig. 1). Occasionally, only pulmonary hyperinflation is seen on chest x-ray. Rarely, the chest film may be normal $[87,133]$. Histologically, the picture is of a pure bronchiolitis obliterans without organizing pneumonia or alveolar wall inflammation. The extent of the airway damage and functional impairment is related to the type and amount of fume inhalation.

Treatment of the late fibrotic stage of bronchiolitis obliterans may not be 
Table 2. Setting of exposure to toxic gases, fumes, and mists associated with bronchiolitis obliterans

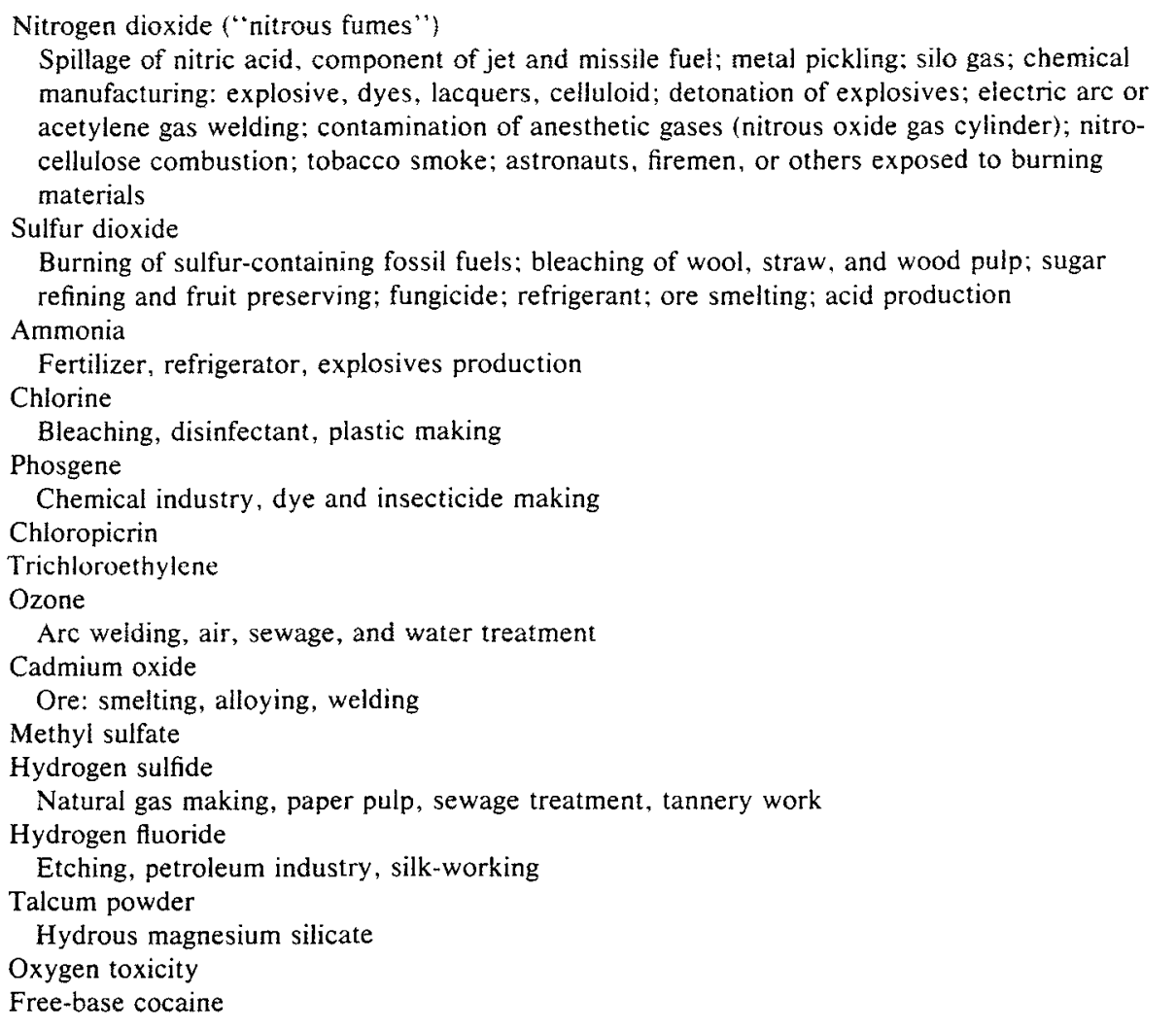

helpful. Therefore, early recognition and treatment of these patients are important. Persons exposed acutely should be observed in the hospital for 48 hs, followed by weekly or biweekly evaluations for 6-8 weeks. Treatment with corticosteroids has been demonstrated to be useful in the management of both the acute phase (i.e., pulmonary edema) and the late phase illness (i.e., bronchiolitis obliterans) $[59,64,85,121]$. Once instituted, therapy should be continued for a minimum of 8 weeks, since relapses have been reported with the premature cessation of therapy $[64,121]$. Treatment may be required for several months to years. Bronchodilators are occassionally helpful and probably should be given a trial in all symptomatic patients.

In general, the prognosis for survivors (one-third die acutely) of toxic fume inhalation is quite good [101]. Those who subsequently develop bronchiolitis obliterans may be permanently disabled and experience progressive disease and death over several months. 


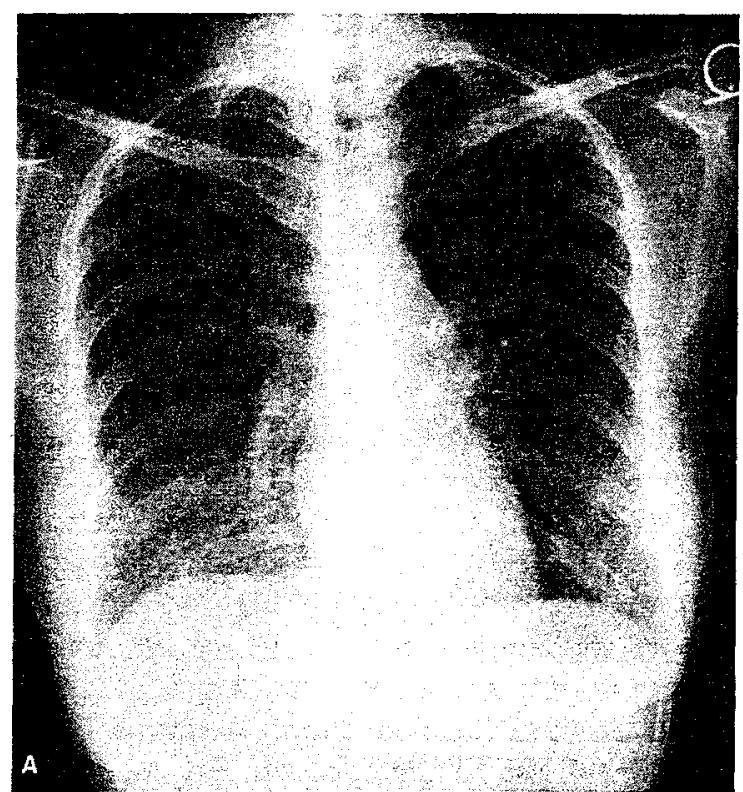

Fig. 1. Bronchiolitis obliterans. A Initial posteroanterior roentgenogram of the chest shows diffuse parenchymal infiltration of a discretely nodular or miliary pattern. B Close-up view of the right lower lobe region demonstrates this nodularity.

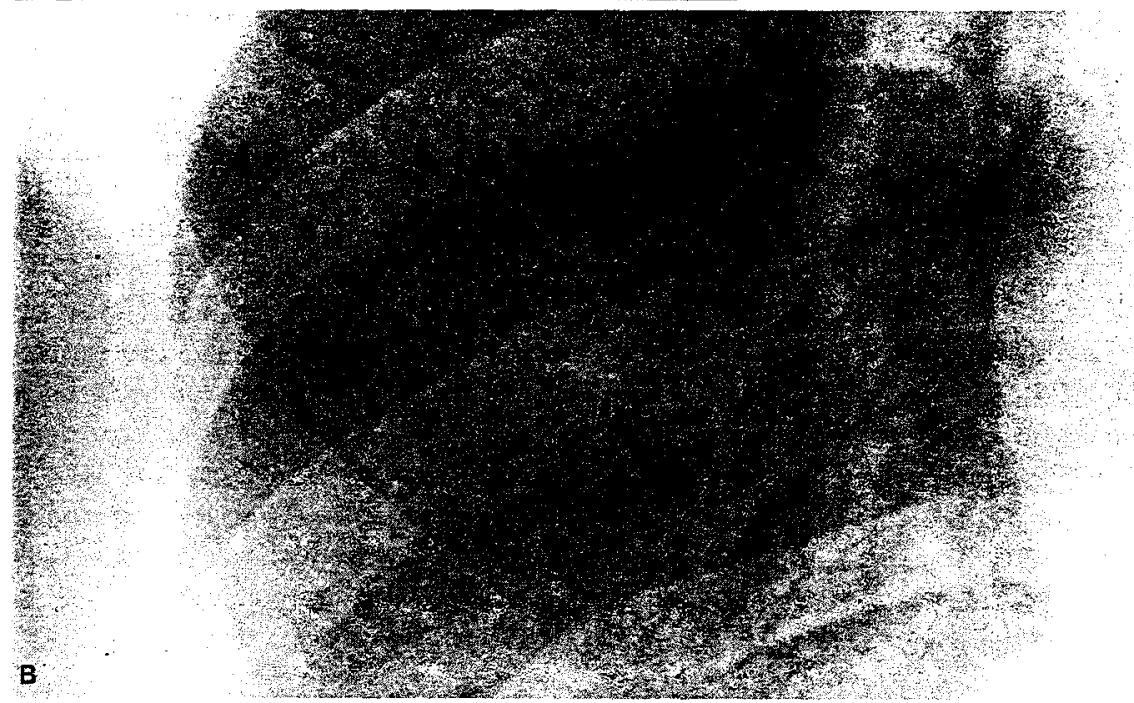

Postinfectious Bronchiolitis Obliterans

Bronchiolitis obliterans is the second most common lower respiratory tract illness requiring hospitalization of infants and young children [113, 131]. It occurs primarily as a result of a viral infection, usually the respiratory syncytial virus (Table 3 ). Infectious bronchiolitis obliterans is rarely seen in children older than age 2 or in adults. When it occurs in older children and young adults, 
Table 3. Infectious causes of bronchiolitis obliterans

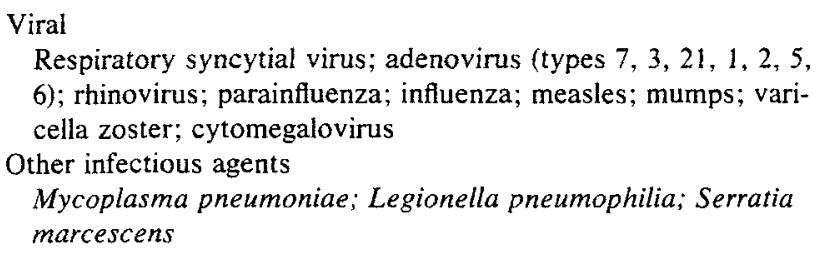

it has been associated primarily with Mycoplasma pneumoniae, but a number of other viral and bacterial agents have also been identified [23, 30, 43, 106]. The disease may also occur as a nonspecific localized process adjacent to a fungal or mycobacterial granuloma [65].

The children usually present with an acute illness that begins with mild coryza with sneezing. Several days later, cough, dyspnea, tachypnea, tachycardia, fever, chest wall retraction, sibilant and sonorous rales, expiratory wheezing, and, in the worst cases, cyanosis may develop. Prostration and respiratory failure are unusual. Recovery is usual and occurs in days or weeks $[47,113,131]$. The clinical presentation in adults has not been well characterized since no systematic study of infectious bronchiolitis obliterans in this group has been reported. Most patients have a history of an upper respiratory tract illness that precedes the onset of dyspnea with exertion, cough, tachypnea, fever, and wheezing $[30,53,93]$. A number of adults have developed an acute or subacute diffuse ventilatory obstruction that has occasionally been fatal.

The radiographic pattern of childhood bronchiolitis is variable. It may be normal or show hyperinflation with increased bronchial markings. Subsegmental consolidation and collapse may be seen [129]. A pattern similar to diffuse interstitial pneumonia often in association with hyperinflation is seen. Some patients demonstrate a diffuse nodular or reticulonodular pattern while others may have patchy alveolar or ground-glass opacities $[10,44]$. Those with nodular pattern frequently have "pure" bronchiolitis obliterans on lung biopsy, whereas those with the reticulonodular pattern are likely to have more interstitial inflammation and scarring $[10,44,131]$. It is interesting that 1 of the longterm complications of this condition is the development of the Swyer-JamesMacLeod syndrome, (i.e., unilateral hyperlucent lung) [24, 69].

Tests of lung function are usually normal, although increases in both endexpiratory lung volume and lung resistance have been reported. Dynamic compliance and arterial hypoxemia have been demonstrated [47, 130, 131]. It has been demonstrated that viral bronchitis may cause abnormalities in lung function that include "small airways dysfunction," reduced diffusing capacity, and frequency dependence of compliance [23]. Whether or not bronchiolitis in infancy predisposes to asthma or COPD in later life remains unprove but data suggesting such an association have appeared in the literature $[47,52,78,79$, 128]. 
The pathologic features of acute viral bronchiolitis have been previously summarized $[44,82,83,133]$. The earliest change is necrosis of the respiratory epithelium followed by proliferation. Dense plugs of alveolar debris and strands of fibrin are seen within small bronchi and bronchioles causing partial or complete obstruction. A lymphocytic infiltrate with germinal centers may be seen in the airway wall. Occasionally, severe and widespread destruction of the respiratory epithelium may cause denudation and a pronounced inflammatory response that may involve the adjacent peribronchial space and alveolar walls. The pathogenetic mechanisms involved in the development of obliterative bronchiolitis secondary to infections and the reason for the predilection in infants are unknown $[84,131]$.

Treatment is symptomatic, with oxygen therapy and adequate hydration being most important [31, 40, 84, 131]. Bronchodilators, antibiotics, and corticosteroids have no proven role in management. Mechanical ventilation is rarely required but may be necessary if progressive respiratory failure ensues.

Occasionally, localized areas of bronchiolitis obliterans are found at open lung biopsy performed to rule out carcinoma. These lesions present radiographically as an irregular nodule or irregular sublobar area of air-space consolidation. Surgical resection usually completely resolves this problem. The true origin of these lesions is unknown but it is very likely secondary to a resolving pneumonia.

\section{Bronchiolitis Obliterans of Unknown Etiology}

\section{Bronchiolitis Obliterans and Organizing Pneumonia}

The group of patients who are classified as having idiopathic bronchiolitis obliterans and organizing pneumonia (BOOP) may represent a subset of patients with unrecognized viral syndromes or toxic fume exposures $[28,34,49$, $66,123]$. The disease onset is usually in the fifth and sixth decade and affects men and women equally. A persistent and usually nonproductive cough ( $84 \%$ of patients) is the most common presenting symptom. Frequently, patients experience dyspnea with exertion (65\% of patients) and two-thirds describe their onset as a flulike illness with fever, malaise, fatigue, and cough. Almost three-fourths of the patients have their symptoms for less than 2 months and less than one-fifth of the patients have symptoms for greater than 1 year. Cigarette smoking is not a precipitating factor. In three-fourths of the patients physical examination reveals crackles (Velcro rales). Wheezing has been found in $31 \%$ and is usually present with rales. Clubbing is not found and occasionally a normal physical examination is present.

Lung functional abnormalities are variable and there is relatively little correlation between histopathologic findings and function. Arterial hypoxemia is a universal finding in symptomatic patients. When the effect of smoking is considered, a higher percentage of patients have a restrictive ventilatory defect. Nineteen percent of patients have normal pulmonary function. Relatively few 
studies of exercise gas exchange have been carried out since most of the studies have been retrospective reviews of pathologically defined cases. The diffusing capacity for carbon monoxide is abnormal in $72 \%$ of patients.

The radiographic manifestations are also variable, but a characteristic pattern of bilateral, patchy, ground-glass, or alveolar opacities is seen in $72 \%$ of these cases (Fig. 2). A miliary pattern often confused with miliary tuberculosis has been reported in one-fourth of the patients. It has been proposed that the combination of radiographic and/or physiological evidence of hyperinflation and rales on physical examination is suggestive or bronchiolitis obliterans. This may be true of toxic fume exposure or viral-induced bronchiolitis obliterans, but it should be pointed out that radiographic evidence of hyperinflation is distinctly uncommon in BOOP. Very rarely $(1 \%)$ is the $\mathrm{x}$-ray appearance normal in patients with BOOP. In Epler and co-workers' [34] recent series, it was shown that the severity of the radiographic abnormalities was significantly correlated with the extent of histologic involvement of the respiratory bronchioles and alveolar ducts but not of the larger terminal bronchioles.

In BOOP the extent of involvement of the small airways is variable. The fibrotic process is patchy and usually involves the airspaces with a peribronchiolar distribution. In 1 series [34] 50\% of the cases showed extensive involvement of the terminal and respiratory bronchioles and two-thirds had significant involvement of the alveolar ducts. The cellular infiltrate found in the bronchiolar walls is composed primarily of mononuclear cells, plasma cells, and histiocytes. Occasionally neutrophils are seen in the lumens of these airways. In some instances an acute inflammatory exudate is seen in neighboring alveoli. The fibrotic processes in these cases are interesting: the early lesions are characterized by organization of the inflammatory and fibrinous exudates with proliferating fibroblasts and little collagen deposition. As the lesions progress, well-formed plugs of edematous granulation tissue that involve terminal and respiratory bronchioles appear and are associated with an intense reaction that extends into the alveolar ducts (Fig. 3). Honeycombing is rarely, if ever, seen $[34,66]$. "Cholesterol," "obstructive," or "endogenous lipid" pneumonia is occasionally seen but sometimes can be so marked as to cause confusion in the diagnosis of this process with pneumonias due to exogenous lipid. It is important that the histologic lesions of BOOP appear uniform in appearance. This contrasts with the usual interstitial pneumonia, in which there are areas of varying degrees of interstitial fribrosis with foci of honeycombing and mononuclear cell infiltration throughout the involved lung [34, 66]. Tables 4 and 5 outline the contrasting clinical and pathologic features of bronchiolitis obliterans and usual interstitial pneumonia, a process with which it is frequently confused $[14,66]$.

Corticosteroid therapy is effective and clinical improvement is very common, often occurring within days of initiation of therapy. As many as twothirds of the patients demonstrate complete clinical and physiological recovery following corticosteroid therapy. Death from progressive disease occurs, but is infrequent [60]. Early cessation of corticosteroid therapy may be associated 

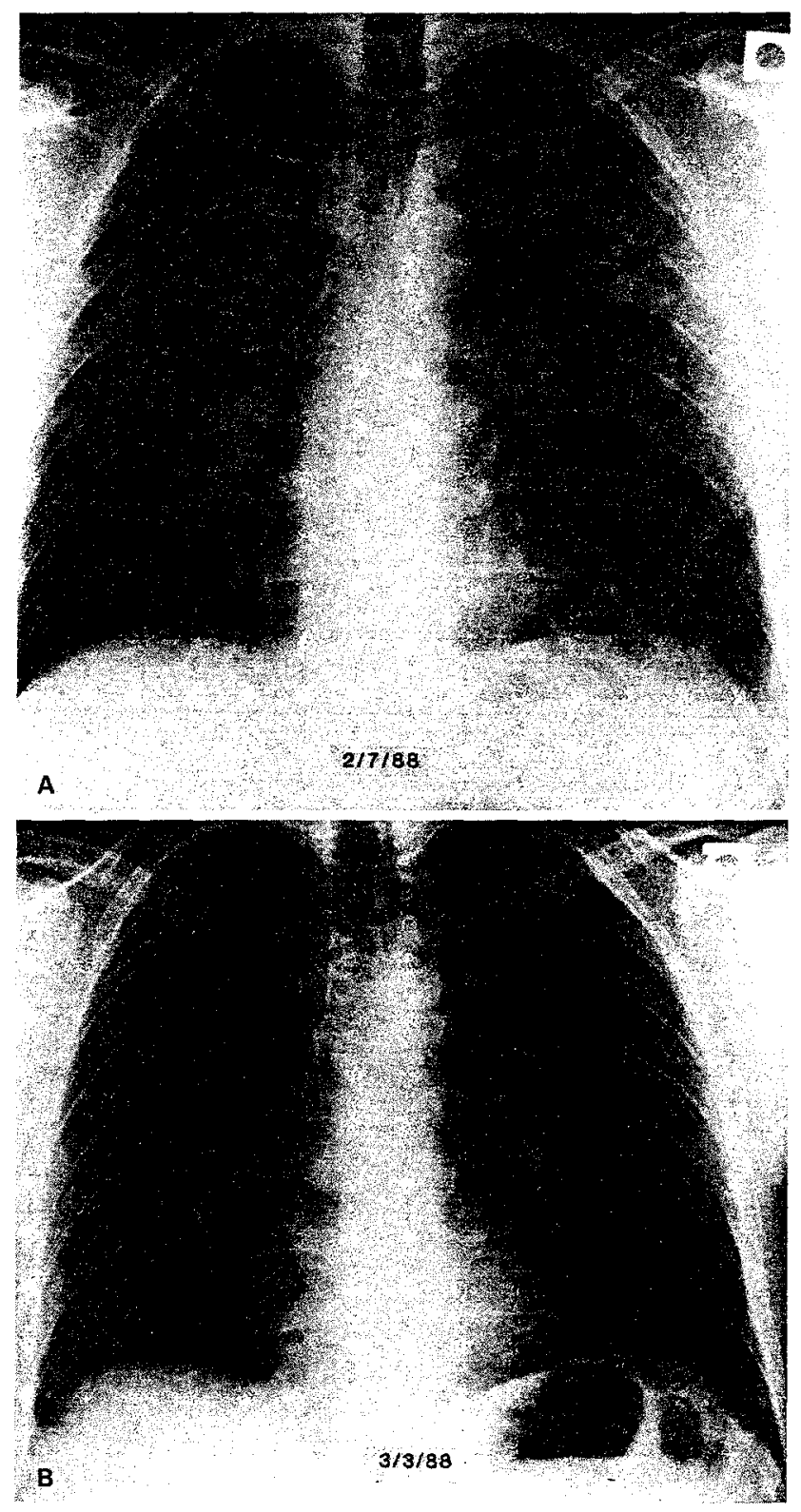

Fig. 2. Bronchiolitis obliterans and organizing pneumonia. Appearance in a 38-year-old patient with 2-week history of progressive dyspnea with exertion and nonproductive cough. A Initial posteroanterior roentgenogram shows mixed alveolar and interstitial infiltrates throughout all lung zones but most prominently in both upper lung zones. B Follow-up posteroanterior roentgenogram, after corticosteroid therapy, documents marked improvement. 


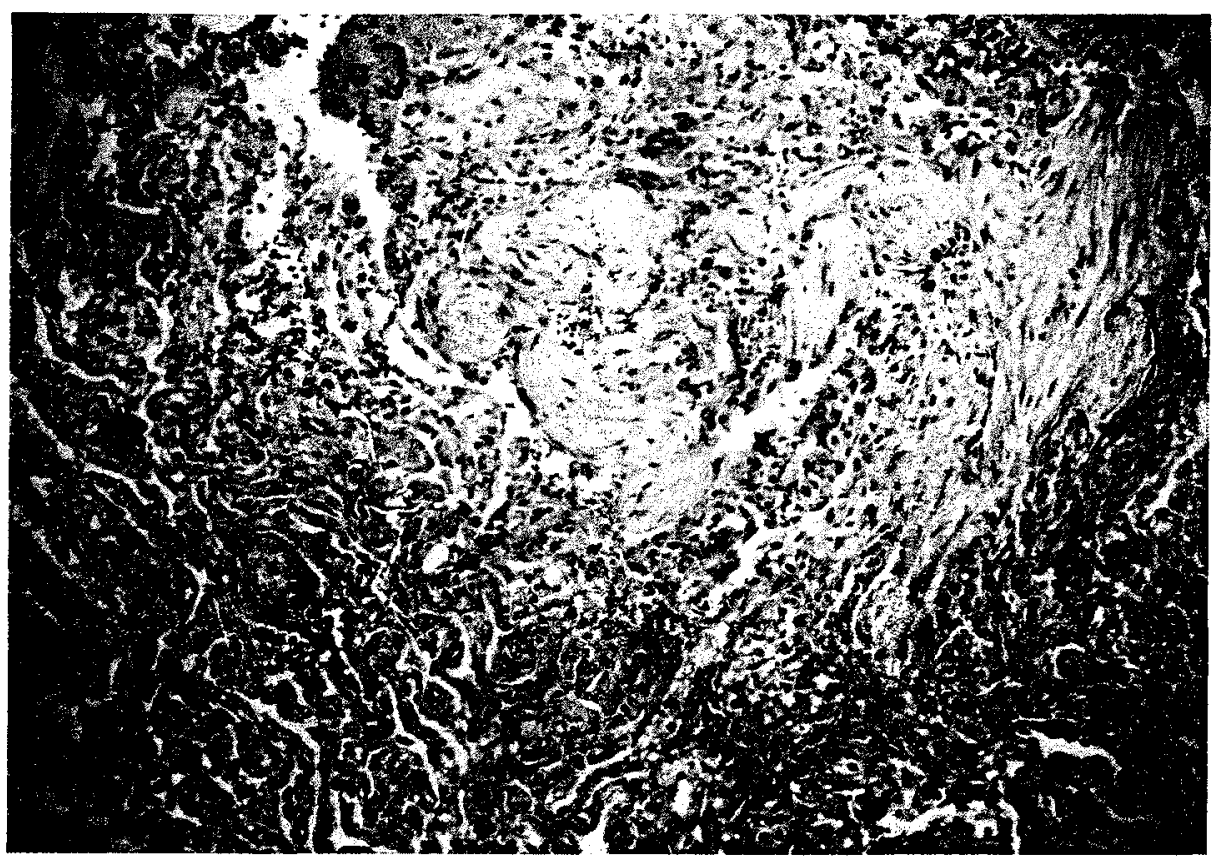

Fig. 3. Bronchiolitis obliterans and organizing pneumonia. Polypoid masses of granulation tissue fill the lumens of respiratory bronchioles and alveolar ducts (top and right). Adjacent alveolar interstices are broadened by a lymphoplasmacytic inflammatory infiltrate, and prominent type II pneumocyte hyperplasia is present $(H \& E, \times 50)$.

with a recurrence of both symptoms and/or radiographic and physiological abnormalities $[27,28,34]$.

\section{Connective Tissue Diseases}

Rheumatoid Arthritis. Pleuropulmonary manifestations are frequently encountered in patients with rheumatoid arthritis (RA): (1) pleural lesions with and without pleurisy; (2) interstitial lung disease; (3) parenchymal rheumatoid nodules; (4) Caplan's syndrome; (5) arteritis; and (6) gold-induced interstitial lung disease. An increased prevalence of obstructive pulmonary disease has been noted $[4,20,26,39,95,108]$. Several studies have demonstrated that factors other than tobacco smoking are involved $[20,42,125,127]$ and bronchiolitis obliterans has recently been recognized as a cause of the airway obstruction in many of these patients $[4,20,21,32,41,48,56,61,62,70,77,88,137]$.

The clinical manifestations of bronchiolitis obliterans associated with RA help to differentiate it from other pulmonary processes associated with RA. There is an abrupt onset of dyspnea and dry cough often associated with inspiratory rales and a midinspiratory squeak. The majority of patients are middle-aged women with seropositive RA, often associated with Sjogren's syn- 
Table 4. Clinical features of bronchiolitis obliterans with organizing pneumonia (BOOP) and idiopathic pulmonary fibrosis

\begin{tabular}{|c|c|c|}
\hline & BOOP & $\begin{array}{l}\text { Idiopathic } \\
\text { pulmonary } \\
\text { fibrosis }\end{array}$ \\
\hline Duration of symptoms (range) & $\begin{array}{l}3 \text { months } \\
\text { (several days- } \\
6 \text { months) }\end{array}$ & $\begin{array}{l}2 \text { yr }(2 \\
\text { months }-5 \text { yr })\end{array}$ \\
\hline \multicolumn{3}{|l|}{ Symptoms (\%) } \\
\hline Cough & 67 & 67 \\
\hline Fever & 58 & 13 \\
\hline Dyspnea & 50 & 100 \\
\hline Upper respiratory infection & 21 & 0 \\
\hline Associated connective tissue disease & 29 & 19 \\
\hline Associated occupation exposure & 0 & 31 \\
\hline \multicolumn{3}{|l|}{ Pulmonary function tests (\%) } \\
\hline Restriction & 40 & 85 \\
\hline Obstruction & 20 & 21 \\
\hline Decreased diffusing capacity of $\mathrm{CO}$ & 50 & 100 \\
\hline \multicolumn{3}{|l|}{ Radiographic manifestations (\%) } \\
\hline Airspace opacities & 50 & 0 \\
\hline Lobar & 46 & 0 \\
\hline Bibasilar & 4 & 0 \\
\hline Interstitial opacities & 42 & 94 \\
\hline Reticular & 42 & 63 \\
\hline Reticulonodular & 0 & 13 \\
\hline Honeycomb & 0 & 19 \\
\hline \multicolumn{3}{|l|}{ Mixed alveolar and interstitial } \\
\hline opacities & 8 & 6 \\
\hline \multicolumn{3}{|l|}{ Lung volume } \\
\hline Decreased & 25 & 75 \\
\hline Normal & 75 & 25 \\
\hline
\end{tabular}

Adopted from refs 14 and 66

Table 5. Contrasting pathologic features of bronchiolitis obliterans with organizing pneumonia and idiopathic pulmonary fibrosis

BOOP Idiopathic pulmonary

fibrosis

\begin{tabular}{lll}
\hline Distribution of lesions & Patchy, peribronchiolar & Diffuse, random \\
Location of lesions & Predominantly airspace & Predominantly interstitial \\
Temporal appearance of changes & Uniform, recent & Varying ages \\
Type of fibrosis & Fribroblastic & Mainly mature (collagen) \\
Honeycomb & Unusual & Common \\
Foamy macrophages & Common & Unusual \\
\hline
\end{tabular}

After ref 66 
drome $[9,76,107]$. The chest radiography is usually normal. Physiological studies usually reveal airflow obstruction, mild to moderate arterial hypoxemia and respiratory alkalosis, and normal pulmonary compliance. The rapid rate of progression of the airflow obstruction is atypical of COPD.

Pathologically, there is a lymphoplasmocytic infiltration of small airway walls. The lumens are gradually obliterated and bronchiolar wall is destroyed by granulation tissue. The lesions are usually confined to the small bronchi and bronchioles but occasionally there is patchy organizing pneumonia with granulation tissue plugs extending into the alveolar ducts. Parenchymal involvement is generally localized to the area surrounding the bronchiolitis. The lesions may be at different stage of development or appear quite uniform $[4,137]$. Immunofluorescence studies show granular IgM or linear IgG depositions along the alveolar septa, suggesting a possible direct immune-mediated lung injury [56, 62].

The prognosis for these patients is poor, with a number of early deaths [41]. Treatment with antibiotics and bronchodilators has been ineffective. Corticosteroid therapy with or without cyclophosphamide appears to be effective in some patients [139].

Penicillamine-Associated Bronchiolitis Obliterans in RA. Penicillamine therapy has been implicated in the pathogenesis of 4 diffuse lung processes: (1) bronchiolitis obliterans; (2) interstitial infiltrates, (3) Goodpasture's syndrome, and (4) bronchopasm $[4,13,15,16,32,62,88,96,115,116,122,132,139]$. The overwhelming majority of the patients with presumed penicillamine-associated bronchiolitis obliterans are women who never smoked. There is a sense that this form of bronchiolitis obliterans is characterized by a rapidly deteriorating course characterized by pulmonary insufficiency [139]. Breathlessness and cough begin within 3-14 months after initiation of penicillamine therapy. In one-third of the cases in which the outcome is known, death from progressive respiratory failure occurs. Radiographic abnormalities are unusual except for mild hyperinflation. Pulmonary function abnormalities are characteristically those of airflow obstruction. The histologic appearance is thought by some to be distinct from that of other causes of bronchiolitis obliterans because the penicillamine-associated cases usually show a concentric, constrictive form of bronchiolar obstruction $[32,41,62,88,96,139]$. Although conclusive proof of association between bronchiolitis obliterans and penicillamine therapy is lacking, when confronted with a dyspneic patient with RA being treated with penicillamine, one should stop use of the drug, consider open lung biopsy, and then administer corticosteroids to prevent disease progression $[32,117]$.

\section{Other Connective Tissue Diseases}

Obstructive airway disease has been reported in patients with Sjogren's syndrome [90]. In fact, a number of these patients had bronchiolitis obliterans and RA [4]. Pathologic studies are limited but in 2 instances lung biopsy revealed 
mononuclear cell infiltration around narrowed small airways. A restrictive ventilatory defect is frequently found in Sjogren's syndrome. This defect probably results from the underlying interstitial lung disease associated with the particular connective tissue disease and is not due to the sicca complex.

Less than $5 \%$ of patients with systemic lupus erythematous (SLE) have airflow obstruction. Kinney and Angelillo [68] have recently reported a patient with SLE who developed rapidly progressive airway obstruction and had early obliterative bronchiolitis on open lung biopsy. This suggested that this lesion may account for the obstructive dysfunction occasionally seen in SLE.

Small airways disease is not frequently found in nonsmokers with scleroderma even in the presence of interstitial pulmonary involvement $[6,50]$. A single case of rapidly fatal bronchiolitis obliterans has been reported in a 57 year-old woman with circulating antinuclear and rheumatoid factors without evidence of a defined connective tissue disease [61]. These authors suggested that the serologic abnormalities could be secondary to the inflammation of the bronchioles. No data exist to support this hypothesis.

Schwarz et al. [109] were among the first specifically to distinguish bronchiolitis obliterans as a de novo process in patients with polymyositis and dermatomyositis. They also suggested that this lesion was corticosteroid responsive.

Small airways disease has been detected in a relatively high percentage of patients with essential mixed cryoglobulinemia, especially if signs of exposure to hepatitis B virus are present [8]. Most of these patients had overall normal lung function, that is, no evidence of airway obstruction or restriction. On the other hand, frequent, although moderate, pulmonary interstitial involvement was present on the chest film in most of these otherwise asymptomatic patients.

Recently, a follicular bronchitis/bronchiolitis has been described in patients with rheumatoid arthritis, Sjogren's syndrome, juvenile rheumatoid arthritis, immunodeficiency syndromes, familial lung disorders, chronic infection, and a heterogeneous group of patients with a hypersensitivity-type reaction $[2,36$, $37,112,138]$. Pathologically, there is a follicular bronchitis/bronchiolitis with abundant germinal centers in the peribronchiolar regions, characterized by hyperplastic follicles located between bronchioles and pulmonary arteries and often compressing the bronchiolar lumen into a slitlike or fish-mouth shape. In almost all cases, a concentric inflammatory infiltrate of lymphocytes and plasma cells surrounded the bronchiole. Patients with rheumatoid arthritis usually presented with dyspnea (100\%); fever and cough occasionally occurred. All have positive rheumatoid factor, often at high levels $(1: 640-1: 2560)$. The chest film was consistently abnormal with bilateral reticulonodular shadows. Pulmonary function tests revealed arterial hypoxemia and hypocapnia, with a widened alveolar-arterial $\mathrm{pO}_{2}$ difference. Both obstructive and restrictive patterns were identified by spirometry, but the restrictive pattern was more common. It has been suggested that this lesion may be the precursor of an interstitial lymphoid pneumonia or pseudolymphoma. It appears to be distinct from bronchiolitis obliterans, since the lesions of follicular bronchiolitis obstruct by external compression of the bronchioles rather than the direct luminal occlu- 
sion characteristic of bronchiolitis obliterans. Treatment with corticosteroids has yielded variable results.

\section{Organ Transplantion}

Bone Marrow Transplantation. Acute or chronic graft versus host disease (GVHD) frequently complicates the course of patients undergoing allogeneic bone marrow transplantation [3, 120]. The acute disease involves the skin, liver, and gut. Ninety percent of patients with this complication survive. The syndrome of chronic GVHD occurs in $33 \%$ of long-term survivors of allogeneic transplantation. The protean manifestations of this disorder include sclerodermalike skin lesions, sicca syndrome, oral and esophageal mucositis, malabsorption, chronic liver disease, generalized wasting, infections, and disorders of immune regulation $[3,26,111,118,120]$. Pulmonary disease is uncommon and is usually the result of an infectious pneumonia (bacterial, fungal, or viral) or idiopathic interstitial pneumonitis. In addition, there are reports of lymphocytic bronchitis and lymphoplasmacytic infiltrate of the trachea and large bronchi [5].

Recently, several cases of rapidly progressive airflow obstruction due to bronchiolitis obliterans complicating bone marrow transplantation have been found $[51,63,73-75,94,98,102-105,114,134,135]$. These cases have appeared in the setting of chronic GVHD and this entity has been postulated to play a role in the development of this lung disease. It has been estimated that approximately $10 \%$ of long-term survivors with chronic GVHD develop the complication of severe obstructive pulmonary disease [98].

Patients usually present with symptoms of dry, nonproductive cough, dyspnea with exertion, bibasilar rales, and scattered wheezing. Hypoxemia is common. The chest roentgenogram may show diffuse interstitial infiltrates, but most often in those cases with obstructive lung function the lung fields are normal or hyperinflated. It is important to note that abnormal pulmonary function has been found in a high percentage of patients following bone marrow transplantation, especially in the presence of GVHD. There can be restrictive and/or obstructive ventilatory dysfunction associated with impairment in gas exchange. Bronchial hyperreactivity was also identified in some patients after undergoing transplantation.

An open lung biopsy is usually necessary to diagnose these cases. Since infections are frequent, they should be diagnosed and treated promptly. Bronchoalveolar lavage has not been a useful procedure in these cases $[22,71,103]$.

The pathogenesis of the obstructive ventilatory defect is unknown. Several mechanisms have been postulated. Shuiman et al. [111] described ectasia and a lymphoplasmocytic infiltration of the tracheal submucosal glands and ducts resembling those described in Sjogren's syndrome. In addition, a dense peribronchial lymphoplasmocytic infiltrate was occasionally seen. Other investigators [5] have found a lymphocytic bronchitis, characterized by lymphocyteassociated necrosis of the bronchial mucosa and submucosal glands. This was 
often associated with an increased incidence of bronchopneumonia and acute bronchitis with mucous plugging. Bronchiolitis obliterans was not noted in this study. Lymphocytic bronchitis is thought to represent a pulmonary manifestation of GVHD. However, others have questioned its association with acute GVHD $[51,75]$. Most patients with rapidly progressive airflow obstruction in whom lung biopsy has been obtained revealed marked lymphocytic or plasma cell and neutrophilic infiltration of the walls of the terminal respiratory bronchioles and obliteration of the bronchiolar lumina with fibrous tissue and surrounding interstitial fibrosis, that is, "pure" bronchiolitis obliterans $[94,98,102,105$, 134]. Since chronic GVHD is associated with a fibrosing process in other organs, it is not surprising that bronchiolar fibrosis may be an additional manifestation of the chronic GVHD. Chronic GVHD is associated with esophageal and sinus disease that may result in recurrent esophageal aspiration and thus could contribute to the lung injury [111].

The treatment and prognosis of bronchiolitis obliterans associated with bone marrow transplantation are unclear. Bronchodilators and corticosteroids, in the majority of cases, have not improved the airflow limitation. Furthermore, the use of immunosuppressive agents for the treatment of chronic GVHD has had no consistent beneficial effect on pulmonary function. Consequently, it would appear that early recognition and management of this process are required if successful treatment is to be attained. The prognosis is quite variable. A significant number of the patients reported had progressive or persistent disease and many died as a result of respiratory failure.

Heart-Lung Transplation. Heart-lung transplantation is being utilized increasingly for the management chronic lung and/or heart disease: end-stage pulmonary vascular disease, idiopathic cardiomyopathy, coronary artery disease, congenital heart disease, terminal pulmonary lymphangioleiomyomatosis, cystic fibrosis, and end-stage Eizenmenger's syndrome. Recently it has been noted that obliterative bronchiolitis is a major complication in long-term survivors of heart-lung transplantation $[1,11,12,29,45,80,119,136]$. The clinical presentation occurs several months to several years following transplantation. Cough productive of mucopurulent sputum followed by progressive dyspnea is common. The chest examination revealed diffuse coarse crepitations and expiratory rhonchi.

Chest radiographs reveal diffuse peribronchial and interstitial infiltrates with variable pleural thickening and bronchography revealed cylindrical bronchiectasis in those examined. Arterial hypoxemia and hypocapnia are universally present. Pulmonary function tests demonstrate irreversible airflow obstruction, often with an associated reduction in total lung capacity. The diffusing capacity of carbon monoxide is moderately depressed. Spontaneous improvement does not occur often.

On pathologic examination, patients have evidence of bronchiolitis obliterans with patchy involvement throughout all areas of the lung [136]. Mucus inspissation and distal obstructive changes were frequently associated. Diffuse increases in peribronchial and interstitial fibrosis were present in all biopsy 
specimens. Pleural, venous, and arteriosclerotic vascular changes were common. These changes are different from those of the acute pulmonary rejection, which is characterized by perivascular lymphocytic cuffing and diffuse alveolar damage.

Yousem and co-investigators [136] have suggested the following as possible causes of bronchiolitis obliterans in patients who have undergone heart-lung transplantation: (1) recurrent or persistent bacterial or viral infections; (2) immune reaction to transplanted lung, for example, GVHD or transplant rejection; (3) altered mucociliary clearance as a result of impaired ciliary function caused by injury to the pulmonary nerve supply or abnormal mucus chemistry and viscosity; (4) bronchial artery ligation leading to alteration in the repair process of injured bronchi and bronchioles; (5) reaction to immunosuppressive drugs, especially cyclosporine, which has been shown to have fibroproliferative properties that could cause progressive narrowing and obliteration of the affected bronchioles; and (5) loss of cough reflex and aspiration leading to the establishment of a milieu necessary to encourage the continued and persistent growth of infectious agents.

No clearly useful treatment protocol has been found. Corticosteroids, bronchodilators, and antibiotics have been used without any documented stabilization or reversal of disease in the majority of patients. Recently, an immunosuppressive regimen of cyclosporine, prednisone, and azathioprine has been suggested as effective in treating bronchiolitis obliterans. A prospective study utilizing this regimen is required to determine its efficacy $[1,45]$. Retransplantation has been a successful alternative in patients with progressive disease.

\section{Miscellaneous Processes}

\section{Idiopathic Pulmonary Fibrosis}

Hamman and Rich [54] mentioned small airway narrowing in their original cases of rapidly progressive idiopathic pulmonary fibrosis. Liebow and Carrington [72] described this lesion superimposed on a background of usual interstitial pneumonia. Some cases of bronchiolitis obliterans and organizing pneumonia have a rapidly progressive course resulting in death that is very similar to the Hamman-Rich syndrome. Since this lesion is frequently confused with IPF, one wonders if many of these cases of Hamman-Rich syndrome are not examples of BOOP.

\section{Hypersensitivity Pneumonitis}

Interstitial pneumonitis (100\%) and granulomas (70\%) are the most common pathologic abnormalities identified in patients with hypersensitivity pneumonitis. However, bronchiolar lesions (bronchiolitis obliterans) are seen in $50 \%$ or more of the patients $[100,110]$ (Fig. 4). A reversible restrictive process is the most common physiological abnormality in chronic hypersensitivity pneumoni- 


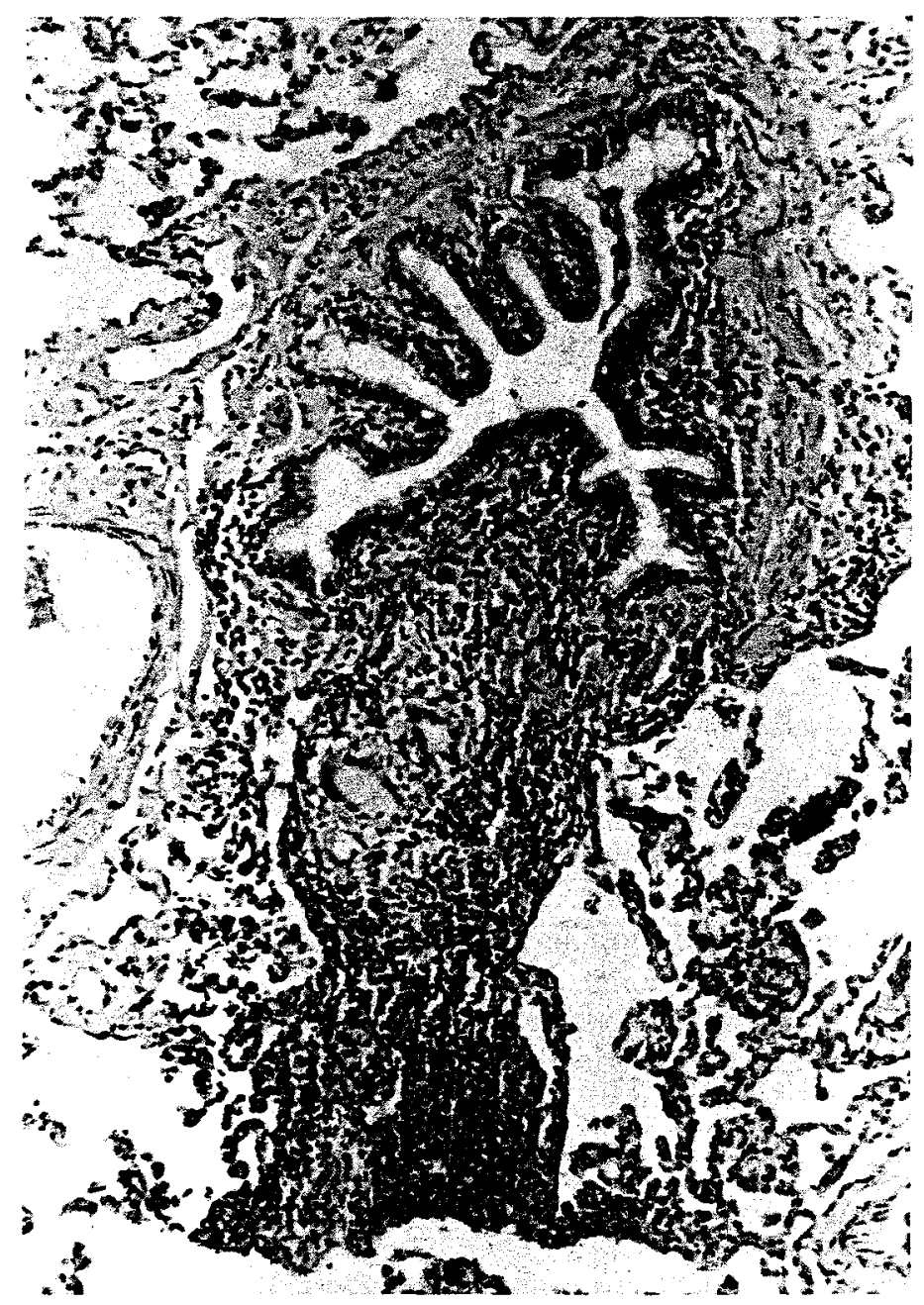

Fig. 4. Hypersensitivity pneumonitis. Narrowing of airway lumen and marked inflammation (bronchiolitis). Multinucleate giant cells are seen in the wall of the airway; a lymphoid aggregate is also present. The surrounding parenchyma is minimally involved.

tis. Small airway dysfunction may be present in patients with early hypersensitivity pneumonitis. As the disease progresses, it may cause both an obstructive or restrictive process depending on the predominant histopathologic process present.

\section{Malignant Histocytosis}

Colby and co-workers [19] described the clinicopathologic spectrum of pulmonary involvement in malignant histiocytosis. The tumor is systemic and com- 
posed of malignant cells with morphologic and functional characteristics of histiocytes. The clinical presentation is variable. Fever, cough, lymphadenopathy, hepatosplenomegaly, and pancytopenia are common. The chest $\mathrm{x}$-ray is frequently abnormal and reveals diffuse bilateral infiltrates (reticular, reticulonodular) or discrete nodules, with or without pleural effusions. Three of 5 patients died within 10 months of presentation. The predominant histologic feature is a nondestructive nodular infiltrate within pulmonary lymphatics and a tendency to invade adjacent structures. Invasion and occlusion of small airways, as well as bronchiolitis obliterans were identified in 3 of the 5 cases reported.

\section{Chronic Eosinophilic Pneumonia}

Eosinophilic pneumonia is a nonspecific term that refers to several entities that have in common pulmonary infiltration with lung and/or blood eosinophilia. The syndrome of chronic eosinophilic pneumonia is characterized by fever, cough, dyspnea, weight loss, and malaise. The disease often waxes and wanes. Physical examination reveals wheezes in some patients. The chest $\mathrm{x}$-ray "typically" shows dense, progressive consolidation that frequently appears in the periphery of the lungs without a clear relationship to segmental and lobar anatomy. The histopathologic features are primarily characterized by infiltration of many mature eosinophils and a small number of lymphocytes and plasma cells. Multinucleated giant cells, Charcot-Leyden crystals, sarcoidlike granulomata, mild angiitis, edema, and proteinaceous exudates also occur. Bronchiolitis obliterans is a rare abnormality in the process $[38,86]$.

\section{Diffuse Panbronchiolitis}

Homma and co-workers [58] recently described their experience with 82 histologically confirmed cases collected through a nationwide survey in Japan. The disease is most prevalent in men. The age of onset is variable. Chronic cough, exertional dyspnea, wheezing, and chronic parasinusitis are the common clinical manifestations of this disease. Pulmonary function tests reveal marked obstructive ventilatory defect and hypoxemia. The chest roentgenogram often reveals small nodular shadows (up to $2 \mathrm{~mm}$ in diameter) diffusely throughout both lung fields. Hyperinflation may also be present. On pathologic examination the lesions are characterized by thickening of the walls of respiratory bronchioles with infiltration of lymphocytes, plasma cells, and histiocytes, and extension of the inflammatory changes toward peribronchiolar tissue. Advanced disease is manifested by secondary ectasia of proximal bronchioli. The prognosis is often poor with rapid progress and a fatal outcome. 


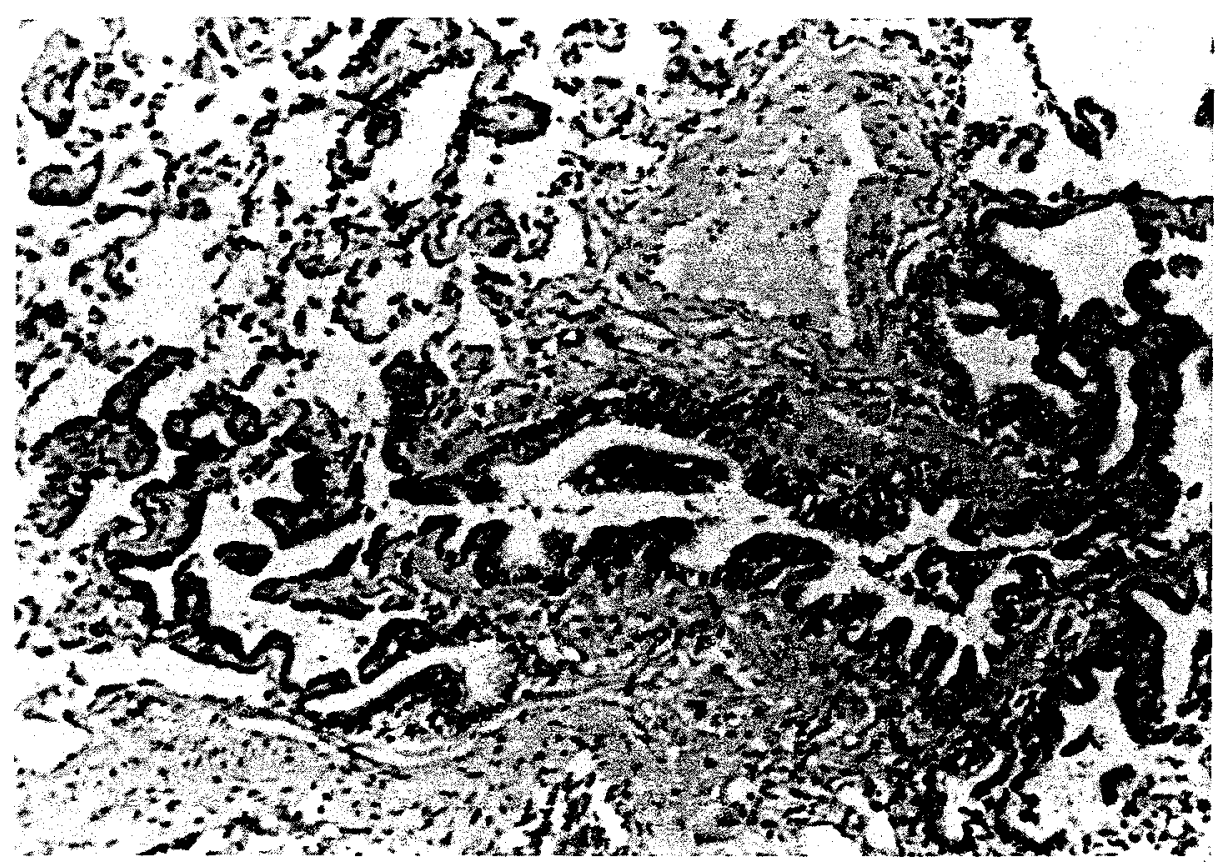

Fig. 5. Respiratory bronchiolitis. Low magnification reveals a bronchiole that is ectatic and has mucus stasis. The walls are thickened and there is extension of the bronchiolar metaplastic epithelium into the terminal bronchiole and aiveolar duct.

\section{Respiratory Bronchiolitis}

Respiratory bronchiolitis is a distinct pathologic lesion commonly found in cigarette smokers [58]. It is characterized by the accumulation of pigmented alveolar macrophages within respiratory bronchioles and adjacent air spaces, often associated with mild thickening of the peribronchiolar interstitium (Fig. 5). It is occasionally seen in nonsmokers and thus may be associated with other environmental or occupational insults. Recognized primarily in autopsy specimens from victims of sudden death or in lungs excised for unrelated solitary nodule, it has generally been considered of little clinical consequence. Recently, it has been recognized that respiratory bronchiolitis is an uncommon cause of chronic lung disease, primarily in heavy cigarette smokers [7, 92]. It is often confused with idiopathic pulmonary fibrosis because the patients present with cough, dyspnea, and have crackles on physical examination. Diffuse interstitial infiltrates are present on the chest radiograph and pulmonary function tests reveals mild to moderate restriction and reduced diffusing capacity.

Respiratory bronchiolitis also occurs in patients with mineral dust exposure, such as asbestos. This is thought to be an early tissue reaction, with 
scarring and inflammation in the membranous bronchioles; commonly these lesions contain a large amount of pigment $[17,18]$.

Acknowledgment. This work was supported in part by SCOR Grant HL 27353 from the National Heart, Lung and Blood Institute.

\section{References}

1. Allen MD, Bruke CM, McGregor CGA, Baldwin JC, Jamieson SW, Theodore J (1986) Steroid-responsive bronchiolitis after human heart lung transplantation. J Thorac Cardiovasc Surg 92:449 -450

2. Athreya BH, Doughty RA, Bookspan M, Schumacher HR, Sewell EM, Chatten J (1980) Pulmonary manifestations of juvenile rheumatoid arthritis. A report of eight cases and review. Clin Chest Med 1:361-374

3. Atkinson K. Storb R. Prentice RL. Weiden PL, Witherspoon RP. Sullivan K. Noel D. Thomas ED (1979) Analysis of late infections in 89 long-term survivors of bone marrow transplantation. Blood 53:720-731

4. Begin R, Masse S, Cantin A, Menard HA, Bureau MA. (1982) Airway disease in a subset of nonsmoking rheumatoid patients. Characterization of the disease and evidence for an autoimmune pathogenesis. Am J Med 72:743-750

5. Beschorner WE, Saral R, Hutchins LM, Tutschka PJ, Santos GW (1978) Lymphocytic bronchitis associated with graft versus host disease in recipients of bone marrow transplants. N Engl J Med 229:1030-1035

6. Bjerke RD, Tashkin DP. Clements DJ. Chopra SK. Gong H Jr. . Bein M (1979) Small airways in progressive systemic sclerosis. Am J Med 66:201-209

7. Bogin RM, Niccoli SA, Waldron JA, Cherniack RM, Thurlbeck WM, Flint A, Colby TV, Schwarz MI, King TE Jr (1988) Respiratory bronchiolitis: clinical presentation and bronchoalveolar lavage findings. Chest 94:21S

8. Bombardieri S, Paoletti P, Ferri C. Di Munno O, Fornal E, Giuntini C (1979) Lung involvement in essential mixed cryoglobulinemia. Am J Med 66:748-755

9. Brannen HM, Goud CA, Divertie MB, Baggenstoss AH (1964) Pulmonary disease associated with rheumatoid arthritis. JAMA 189:914-918

10. Breatnach E, Kerr I (1982) The radiology of cryptogenic obliterative bronchiolitis. Clin Radiol 33:657-661

11. Burke CM, Theodore J, Dawkins KD, Yousem SA, Blank N, Billingham ME, VanKessel A, Jamieson SW, Oyer PE, Baldwin JC, Shinson EE, Shumway NE, Robin ED (1984) Posttransplant obliterative bronchiolitis and other late lung sequelae in human heart-lung transplantation. Chest 86:824-829

12. Burke CM, Theodore J, Baldwin JC, Tazelaar HD, Morris AJ, McGregor C, Shumway NE, Robin ED, Jamieson SW (1986) Twenty-eight cases of human heart-lung transplantation. Lancet 1:517--519

13. Camus $\mathbf{P}$ (1982) The respiratory complications of $\mathbf{D}$-penicillamine therapy (authro's translation). Rev Fr Mal Respir 10:7-20

14. Chandler PW, Shin MS, Friedman SE, Myers JL, Katzenstein A-L (1986) Radiographic manifestations of bronchiolitis obliterans with organizing pneumonia vs usual interstitial pneumonia. AJR 147:899-906

15. Chebat J, Seigneur F, Lechien J, Menkes CJ, Simon F, Martin JL (1980) Obliterating bronchiolitis during D-penicillamine treatments (letter). Nouv Presse Med 9:2655

16. Chebat J, Seigneur F, Lechien J, Caubarrère I, Menkes CJ (1981) Bronchiolite sevère au cour de trois cas de polyartérite rhumatoide traitée par D-penicillamine. Rev Fr Mal Respir 9:147149

17. Churg A, Wright JL (1983a) Small airways disease in persons exposed to nonasbestos mineral dusts. Hum Pathol 14:688-693 
18. Churg A, Wright JL (1983b) Small airway disease in mineral dust exposure. Pathol Annu $18: 233$

19. Colby TV, Carrington CB, Mark GJ (1981) Pulmonary involvement of malignant histiocytosis: a clinicopathologic spectrum. Am J Surg Pathol 5:61-73

20. Collins RL, Turner RA, Johnson AM, Whitley NO, McLean RL (1976) Obstructive pulmonary disease in rheumatoid arthritis. Arthritis Rheum 19:623-628

21. Cooney TP (1981) Interrelationship of chronic eosinophilic pneumonia, bronchiolitis obliterans, and rheumatoid disease: a hypothesis. J Clin Pathol 34:129-137

22. Cordonnier C, Bernaudin JF, Feuilhade M, Fleury J, Pocholle MJ, Haioun C, Deforges L, Bierling P, Atassi K, Lampron N, Payen D, Huet Y, Vernant JP (1984) Diagnostic value of bronchoalveolar lavage (BAL) in pneumonitis occurring after allogeneic bone marrow transplantation (BMT). Exp Hematol 12(suppl 15):26

23. Coultas DB, Samet JM, Butler C. (1986) Bronchiolitis obliterans due to Mycoplasma pneumoniae. West J Med 144:471-474

24. Daniel TL, Woodring JH, Vandiviere HM, Wilson HD (1984) Swyer-James syndromeunilateral hyperlucent lung syndrome. A case report and review. Clin Pediatr 23:393-397

25. Darke CS, Warrack AJN (1958) Bronchiolitis from nitrous fumes. Thorax 13:327-333

26. Davidson C, Brook AGF, Bacon PA (1974) Lung function in rheumatoid arthritis. Ann Rheum Dis 33:293-297

27. Davison AG, Heard BE, McAllister WAC, Turner-Warwick MEH (1982) Steroid responsive relapsing cryptogenic organizing pneumonitis. Thorax 37:785-786

28. Davison AG, Heard BE, McAllister WAC, Turner-Warwick MEH (1983) Cryptogenic organizing pneumonitis. Q J Med 52:382-394

29. Dawkins KD, Jamieson SW, Hunt SA, Baldwin JC, Burke CM, Morris A, Billingham ME. Theodore J, Oyer PE, Stinson EB, Shumway NE (1985) Long-term results, hemodynamics, and complications after combined heart and lung transplantation. Circulation 71:919-926

30. Dines DE (1967) Acute bronchiolitis as a cause of chronic obstructive lung disease in adults. Report of two cases. J Lancet 87:281-282

31. Ellis EF (1977) Therapy of acute bronchiolitis. Pediat Res 11:263-264

32. Epler GR, Snider GL, Gaensler EA, Cathcart ES, FitzGerald MX, Carrington CB. (1979) Bronchiolitis and bronchitis in connective tissue disease. A possible relationship to the use of penicillamine. JAMA 242:528-532

33. Epler GR, Colby TV (1983) The spectrum of bronchiolitis obliterans. Chest 83:161-162

34. Epler GR, Colby TV, McLoud TC, Carrington CB, Gaensler EA (1985) Bronchiolitis obliterans organizing pneumonia. N Engl J Med 312:152-158

35. Fleming GM, Chester EH, Montenegro HD (1979) Dysfunction of small airways following pulmonary injury due to nitrogen dioxide. Chest 75:720-721

36. Fourtoul-van-der Goes T, Canno-valle F, Barrios-de-valle R (1981) Follicular bronchiolitis in connective tissue disease and its reprecussions in the pulmonary arteries. Arch Inst Cardiol Med 51:267

37. Fortoul TI, Cano-Valle F, Oliva E, Barrios R (1985) Follicular bronchiolitis in association with connective tissue diseases. Lung 163:305-314

38. Fox B, Seed WA (1980) Chronic eosinophilic pneumonia. Thorax 35:570-580

39. Frank ST, Weg JG, Harkleroad LE, Fitch RF (1973) Pulmonary dysfunction in rheumatoid disease. Chest 63:27-34

40. Friis B, Andersen P, Brene E, Hornsleth A, Jensen A, Knudsen FU, Krasilnikoff PA, Mordhorst CH, Nielsen S, Uldall P (1984) Antibiotic treatment of pneumonia and bronchiolitis. A prospective randomized study. Arch Dis Child 59:1038-1045

41. Geddes DM, Corrin B, Brewerton DA, Davies RJ, Turner-Warwick M (1977) Progressive airway obliteration in adults and its association with rheumatoid disease. Q J Med 46:427-444

42. Geddes DM, Webley M, Emerson PA (1979) Airways obstruction in rheumatoid arthritis. Ann Rheum Dis 38:222-225

43. Goldstein JD, Godleski JJ, Balikian JP, Herman PG (1982) Pathologic patterns of Serratia marcescens pneumonia. Hum Pathol 13:479-484 
44. Gosink BB, Friedman PJ, Liebow AA (1973) Bronchiolitis obliterans: roentgenologic-pathologic correlation. Am J Roentgenol 117:816-832

45. Granville AR, Baldwin JC, Burke CM, Theodore J, Robin ED (1987) Obliterative bronchiolitis after heart-lung transplantation: apparent arrest by augmented immunosuppression. Ann Intern Med 107:300-304

46. Graze PR, Gale RP (1979) Chronic graft versus host disease: a syndrome of disordered immunity. Am J Med 66:611-620

47. Green M. Bronchiolitis (1974) In: Sadaul P, Milic-Emili J, Simonsson BG, Clark TJH (eds) Small airways in health and disease. Exerpta Medica, Amsterdam, pp 90-94

48. Green M, Turton CW (1982) Bronchiolitis and its manifestations. Eur J Respir Dis 121S:3642

49. Grinblat J, Mechlis S, Lewitus $Z$ (1981) Organizing pneumonia-like process. An unusual observation in steroid responsive cases with features of chronic interstitial pneumonia. Chest $80: 259-263$

50. Guttadauria M, Ellman H. Emmanuel G, Kaplan D, Diamond H (1977) Puimonary function in scleroderma. Arthritis Rheum 20:1071-1079

51. Hackman RC, Sale GE (1981) Large airway inflammation as a possible manifestation of a pulmonary graft-versus-host reaction on bone marrow allograft recipients (abstract). Lab Invest $44: 26 \mathrm{~A}$

52. Hall WJ, Hall CB (1979) Clinical significance of pulmonary function tests. Alterations in pulmonary function following respiratory viral infection. Chest 76:458-465

53. Ham JC (1964) Acute infectious obstructing bronchiolitis: a potentially fatal disease in the adult. Ann Intern Med 60:47-60

54. Hamman L, Rich AR (1944) Acute diffuse interstitial fibrosis of the lung. Bull Johns Hopkins Hosp 74:177-212

55. Harris C (1965) Acute obstructive bronchiolitis. Presentation of fatal case. JAMA 194:203205

56. Herzog CA, Miller RR, Hoidal JR (1981) Bronchiolitis and rheumatoid arthritis. Am Rev Respir Dis 124:636-639

57. Hogg JC, Williams J, Richardson JB, Macklem PT, Thurlbeck WM (1970) Age as a factor in the distribution of lower airway conductance and in the pathologic anatomy of obstructive lung disease. N Engl J Med 282:1283-1287

58. Homma H, Yamanaka A, Tanimoto S, et al (1983) Diffuse panbronchiolitis: a disease of the transitional zone of the lung. Chest 83:63 -69

59. Horvath EP, Dolico DGA, Barbee RA, Dickie HA (1978) Nitrogen dioxide-induced pulmonary disease. J Occup Med 20:103-110

60. Iannuzzi MC, Farhi DC, Bostrom PD, Petty TL, Fisher JH. (1985) Fulminant respiratory failure and death in a patient with idiopathic bronchiolitis obliterans. Arch Intern Med 145:733-734

61. Jacobs P, Bonnyns M, Depierreux M, Duchateau J, Sergysels R. (1984) Rapidly fatal bronchiolitis obliterans with circulating antinuclear and rheumatoid factors. Case report. Eur J Respir Dis 65:384-388

62. Jansen HM, Elema JD, Hylkema BS, vanLeeuwen MA, The TH, van der Mark TW, Sluiter HJ (1982) Progressive obliterative bronchiolitis in a patient with rheumatoid arthritis. Eur J Respir Dis 121:43-52

63. Johnson FL, Stokes DC, Ruggiero M, Dalla-Pozza L, Callihan TR (1984) Chronic obstructive airways disease after bone marrow transplantation. J Pediatr 105:370-376

64. Jones GR, Proudfoot AT, Hall JI (1973) Pulmonary effects of acute exposure to nitrous fumes. Thorax 28:61-65

65. Katzenstein AL, Askin FB (1982) Surgical pathology of non-neoplastic lung disease. WB Saunders, Philadelphia, pp 349-356

66. Katzenstein ALA, Myers JL, Prophet WD, Corley LS III, Shin MS (1986) Bronchiolitis obliterans and usual interstitial pneumonia. A comparative clinicopathologic study. Am J Surg Pathol 10:373-381

67. King TE Jr (1988) Bronchiolitis obliterans. In: Schwarz MI, King TE Jr (eds) Interstitial lung disease. BC Decker, Toronto, pp 325-342 
68. Kinney WW, Angelillo VA (1982) Bronchiolitis in systemic lupus erythematosis. Chest 82:646-649

69. Kogutt MS, Swischuk LE, Goldblum R (1973) Swyer-James syndrome (unilateral hyperlucent lung) in children. Am J Dis Child 125:614-618

70. Lahdensuo A (1984) Bronchiolitis in rheumatoid arthritis. Chest 85:705-708

71. Leskinen R, Tukianinen P, Taskinen E, Volin L, Renkonen R, Ruuth T, Hayry P (1984) Bronchoalveolar lavage in the diagnosis of pulmonary complications in bone marrow transplant recipients. Preliminary experience. Exp Hematol 12(suppl 15):24-25

72. Liebow AA. Carrington CB (1969) The interstitial pneumonials. In: Simon M. Potchen EJ. LeMay $M$ (eds) Frontiers of pulmonary radiology. Grune \& Stratton. New York. $p$ 102

73. Link H, Reinhard D, Neithammer D, Kruger GRF, Waller HD, Wilms K (1982) Obstructive ventilation disorders as a severe complication of chronic graft-versus-host disease after bone marrow transplantation. Exp Hematol 10:92-93

74. Link H, Ostendorf P, Wilms K, Reinhard U, Schuch K, Walter E, Niethammer D, Waller HD (1983) Pulmonary complications after bone marrow transplantation. Exp Hematol 11(suppl 14):125-127

75. Link H, Ostendorf $P$, Wernet $P$, Reinhard U, Waiter E, Fischbach H, Niethammer D, Waller HD (1984) Pulmonary complication after allogeneic bone marrow transplantation. The Tubingen experience. Exp Hematol 12(suppl 15):21-22

76. Macfarlane JD, Dieppe PA, Ridgen BG, Clark TJH (1978) Pulmonary and pleural lesions in rheumatoid disease. Br J Dis Chest 72:288-300

77. McCann BG (1983) Obliterative bronchiolitis and upper zone pulmonary consolidation in rheumatoid arthritis. Thorax 38:73-74

78. McConnochie KM, Roghmann KJ (1985) Predicting clinically significant lower respiratory tract illness in childhood following mild bronchiolitis. Am J Dis Child 139:625-631

79. McConnochie KM, Mark JD, McBride JT, Hall WJ, Brooks JG, Klein SJ, Miller RL, McInerny TK, Nazarian LF, MacWhinney JB (1985) Normal pulmonary function measurements and airway reactivity in childhood after mild bronchiolitis. J Pediatr 107:54-58

80. McGregor CG, Jamieson SW, Baldwin JC, Burke CM, Dawkins KD, Stinson EB, Dyer PE, Billingham ME, Zusman DR, Reitz BA, Morris A, Yousem S, Hunt SA, Shumway NE (1986) Combined heart-lung transplantation for end-stage Eisenmenger's syndrome. J Thorac Cardiovasc Surg 91:443-450

81. McIntosh K (1976) Bronchiolitis and asthma: possible common pathogenetic pathways. J Allergy Clin Immunol 57:595-604

82. McLean $\mathrm{KH}$ (1956) The pathology of acute bronchiolitis: a study of its evolution. 1. The exudative phase. Aust Ann Med 5:254-267

83. McLean KH (1957) The pathology of acute bronchiolitis: a study of its evolution. II. The repair phase. Aust Ann Med 6:29-43

84. Mellins RB (1977) Bronchiolitis-comments on pathogenesis and treatment. Pediatr Res 11:268-269

85. Milne JEH (1980) Nitrogen dioxide inhalation and bronchiolitis obliterans. J Occup Med 11:538-547

86. Morrissey WL, Gaensler EA, Carrington CB, Turner HG (1975) Chronic eosinophilic.pneumonia. Respiration 32:453-468

87. Murphy DMF, Fairman RP, Lapp NL, Morgan KC (1976) Severe airway disease due to inhalation of fumes from cleansing agents. Chest 69:372-376

88. Murphy KC, Atkins CJ, Offer RC, Hogg JC, Stein HB (1981) Obliterative bronchiolitis in two rheumatoid arthritis patients treated with penicillamine. Arthritis Rheum 24:557-560

89. Myers JL, Veal CF Jr, Shin MS, Katzenstein ALA (1987) Respiratory bronchiolitis causing interstitial lung disease. A clinicopathologic study of six cases. Am Rev Respir Dis 135:880884

90. Newhall HH, Brahim SA. (1977) Chronic obstructive airway disease in patients with Sjogren's syndrome. Am Rev Respir Dis 115:295-304

91. Nichols BH (1930) Clinical effects of inhalation of nitrogen dioxide. Am J Roentgenol 23:516520 
92. Niewoehner DE, Kleinerman J, Rice DB (1974) Pathologic changes in the peripheral airways of young cigarette smokers. N Engl J Med 291:755-758

93. O'Reilly JF (1980) Adult bronchiolitis and parainfluenza type 2. Postgrad Med J 56:787-788

94. Ostrow D, Buskard N, Hill RS, Vickars L, Churg A (1985) Bronchiolitis obliterans complicating bone marrow transplantation. Chest 87:828-830

95. Patterson CD, Harrille WE, Pierce JA (1965) Rheumatoid lung disease. Ann Intern Med 62:685-697

96. Penny WJ, Knight RK, Rees AM, Thomas AL, Smith AP (1982) Obliterative bronchiolitis in rheumatoid arthritis. Ann Rheum Dis 41:469-472

97. Prowse K (1977) Nitrous fume poisoning. Bull Europ Physiopathol Respir 13:191-202

98. Ralph DD, Springmeyer SC, Sullivan KM, Hackman RC, Storb R, Thomas ED (1984) Rapidly progressive air-flow obstruction in marrow transplant recipients: possible association between obliterative bronchiolitis and chronic graft-versus-host disease. Am Rev Respir Dis 129:641-644

99. Ramirez RJ, Dowell AR (1971) Silo-filler's disease: nitrogen dioxide-induced lung injury: long-term follow-up and review of the literature. Ann Intern Med 74:569-576

100. Reyes CN, Wenzel FJ, Lawton BR, Emanuel DA (1982) The pulmonary pathology of farmer's lung disease. Chest $81: 142-146$

101. Rigner KG, Swensson A (1961) Late prognosis of nitrous fume poisoning and follow-up study. Acta Med Scand 170:291-299

102. Roca J, Granena A, Rodriguez-Roisin R, Alvarez P, Agusti-Vidal A, Rozman C (1982) Fatal airway disease in an adult with chronic graft-versus-host disease. Thorax 37:77-78

103. Rodriguez-Roisin R, Roca S, Granena A, Agusti-Vidal A, Rozman C (1984) Obliterative bronchiolitis: a distinct pathophysiological form of pulmonary involvement in bone marrow transplantation. Exp Hematol 12(suppl 15):12-14

104. Rodriguez-Roisin R, Roca J, Marin P, Granena A, Agusti-Vidal A, Rozman C (1985) Pulmonary follow-up in patients with bone marrow transplantation (BMT) and graft-versus-host disease (GVHD). Exp Hematol 13(suppl 17):145

105. Rosenberg ME, Vercellotti GM, Snover DC, Hurd D, McGlave P (1985) Bronchiolitis obliterans after bone marrow transplantation. Am J Hematol 18:325-328

106. Sato P, Madtes DK, Thorning D, Albert RK (1985) Bronchiolitis obliterans caused by Legionella pneumophila. Chest 87:840 842

107. Scadding JG. (1969) The lungs in rheumatoid arthritis. Proc R Soc Med 62:227-238

108. Schernthaner G, Scherak D, Kolarz G, Kummer F (1976) Seropositive rheumatoid arthritis associated with decreased diffusion capacity of the lung. Ann Rheum Dis 35:258-262

109. Schwarz MI, Matthay RA, Sahn SA, Stanford RE, Marmorstein BL, Scheinhorn DJ (1976) Interstitial lung disease in polymyositis and dermatomyositis: analysis of six cases and review of the literature. Medicine 55:89-104

110. Seal RME, Hapke EJ. Thomas GO, Meek JC. Hayes M (1968) The pathology of the acute and chronic stages of farmers lung. Thorax 23:469-489

111. Shulman HM, Sullivan KM, Weiden PL, McDonald GB, Striker GE, Sale GE, Hackman R, Tsoi M-S, Storb R, Thomas ED (1980) Chronic graft-versus-host syndrome in man. A longterm clinicopathological study of 20 Seattle patients. Am J Med 69:204-217

112. Simko I (1967) New data to the pathology and clinic of "bronchitis follicularis" in connection with a case confirmed by biopsy. Helv Paediatr Acta 22:591-602

113. Smith CB, Overall CJ Jr (1973) Clinical and epidemiologic clues to the diagnosis of respiratory infections. Radiol Clin North Am 11:261-278

114. Sorensen PG, Ernst P, Panduro J, Moller J (1984) Reduced lung function in leukemia patients ŝ undergoing bone marrow transplantation. Scand J Haematol 32:253-257

115. Stein HB, Patterson AC, Offer RC, Atkins CJ, Teufel A, Robinson HS (1980) Adverse effects of D-penicillamine in rheumatoid arthritis. Ann Intern Med 92:24-29

116. Stein HB, Chalmers A, Schroeder ML, Dillon A (1984) Selected adverse reactions to Dpenicillamine. Clin Invest Med 7:73-76

117. Sternlieb I, Bennet B, Scheinberg IH (1975) D-Penicillamine induced Goodpasture's syndrome in Wilson's disease. Ann Intern Med 82:673-676

118. Sullivan KM, Shulman HM, Storb R, Weiden P, Witherspoon RP, McDonald GB, Schubert 
MM, Atkinson K, Thomas ED (1981) Chronic graft-versus-host disease in 52 patients: adverse natural course and successful treatment with combination immunosuppression. Blood $57: 267-276$

119. Theodore J, Jamieson SW, Burke CM, Reitz BA, Stinson ED, Van Kessel A, Dawkins KD, Herran JJ, Oyer PE, Hunt SA, Shumway NE, Robin ED (1984) Physiologic aspects of human heart-lung transplantation: pulmonary function status of the post-transplanted lung. Chest 86:349-357

120. Thomas ED, Storb R. Clift RA, Fefer A. Johnson FL. Neiman PE, Lerner KG. Glucksberg H. Buckner CD (1975) Bone marrow transplantation. N Engl J Med 292:832-843

121. Tse RL, Bockman AA (1970) Nitrogen dioxide toxicity. Reports of four cases in firemen. JAMA 212:1341-1344

122. Turner-Warwick M (1981) Adverse reactions affecting the lung: possible association with Dpenicillamine. J Rheumatol 7:166-168

123. Turton CW, William G, Green M (1981) Cryptogenic obliterative bronchiolitis in adults. Thorax 36:805-810

124. Twiggs JT, Larson LA, O'Connell EJ, llstrup DM (1981) Respiratory syncytial virus infection: ten-year follow-up. Clin Pediatr (Phila) 20:187-190

125. Vest JV, Smith TW, Gorman JC, Senior RM, Kuhn C (1980) Airways abnormalities in nonsmokers with rheumatoid arthritis. Am Rev Respir Dis 121:202A

126. Von Oettingen WF (1941) The toxicity and potential dangers of nitrous fumes. Public Health Bull 272:1-34

127. Walker WC (1967) Pulmonary infection and rheumatoid arthritis. Q J Med 36:239-251

128. Weiss ST, Tager IB, Munoz A, Speizer FE (1985) The relationship of respiratory infections in early childhood to the occurrence of increased levels of bronchial responsiveness and atopy. Am Rev Respir Dis 131:573-578

129. Wenman WM, Pagtakhan RD, Reed MH, Chernick V, Albritton W (1982) Adenovirus bronchiolitia in Manitoba: epidemiologic, clinical and radiologic features. Chest 81:605-609

130. Wohl ME (1977) Present capacity to evaluate pulmonary function relevant to bronchiolitis. Pediatr Res 11(3Pt2):252-253

131. Wohl MEB, Chernick V (1978) Bronchiolitis: state of the art. Am Rev Respir Dis 118:759781

132. Wolfe F, Schurle,DR, Lin JJ, Polland SM, Smith TW, Montgomery-Short R, James DL. (1983) Upper and lower airway disease in pencillamine treated patients with rheumatoid arthritis. J Pheumatol 10:406-410

133. Woodford DM, Coutu RE, Gaensler EA (1979) Obstructive lung disease from acute sulfure dioxide exposure. Respiration 38:238-245

134. Wyatt SE, Nunn P, Hows JM, Yin HAL, Hayes M, Gordon-Smith EC, Catovsky D, Goldman JM, Galton DAG (1984) Airways obstruction in association with graft-versus-host disease following bone marrow transplantation. Exp Hematol 12(suppl 15):17-18

135. Wyatt SE, Nunn P, Hows JM, Yin J, Hayes MC, Catovsky D, Gordon-Smith EC, Hughes JM, Goldman JM, Galton D (1984) Airways obstruction associated with graft versus host disease after bone marrow transplantation. Thorax 39:887-894

136. Yousem SA, Burke CM, Billingham ME (1985) Pathologic pulmonary alterations in long-term human heart-lung transplantation. Hum Pathol 16:911-923

137. Yousem SA, Colby TV, Carrington CB (1985) Lung biopsy in rheumatoid arthritis. Am Rev Respir Dis 131:770-77?

138. Yousem SA, Colby TV, Carrington CB (1985) Follicular bronchitis/bronchiolitis. Hum Pathol $16: 700-706$

139. van de Laar MA, Westermann CJ, Wagenaar SS, Dinant HJ (1985) Beneficial effect of intravenous cyclophosphamide and oral prednisone on D-penicillamine-associated bronchiolitis obliterans. Arthritis Rheum 28:93-97 